\title{
EARNING PER SHARE, DEBT TO EQUITY RATIO DAN CURRENT RATIO TERHADAP PROFITABILITAS PERUSAHAAN SUB-SEKTOR BARANG KONSUMSI DI BURSA EFEK INDONESIA
}

\author{
Nita Wedyaningsih ${ }^{1)}$, Siti Nurlaela ${ }^{2)}$, Kartika Hendra Titisari ${ }^{3)}$ \\ ${ }^{1,2,3)}$ Program Studi Akuntansi Fakultas Ekonomi Universitas Islam Batik Surakarta \\ e-mail: ${ }^{1)}$ wedyaningsihnita@gmail.com
}

\begin{abstract}
Abstrak : The purpose of this study was to analyze the effect of Earning Per Share, Debt to Equity Ratio and Current Ratio on Profitability (ROA) to the mining company on Indonesian Stock Exchange. The sample in this study were 55 companies in the consumer goods sub sector in 2013 to 2017 which were selected by pupposive sampling method. The analytical method used is multiple analysis using SPSS version 24.0. The result show that simultaneously (F-test) Earning Per Share, Debt To Equity Ratio and Current Ratio has a Profitability (ROA). The partially (t-test) Earning Per Share has no has a effect on profitability (ROA). While the Debt To Equity Ratio and Current Ratio effect on Profitability.
\end{abstract}

Keywords : EPS, DER, CR, ROA

\section{PENDAHULUAN}

Penelitian yang dilakukan oleh (Joana \& Pitaloka, 2017), (Ulzanah \& Murtaqi, 2015) menunjukkan variabel Earning Per Share berpengaruh terhadap Profitabilitas (ROA), Perusahaan yang memiliki Earning Per Share tinggi akan menambah profit perusahaan karena akan mendapatkan laba tinggi. Keuntungan yang tinggi akan meningkatkan pembilang untuk Profitabilitas (ROA).

Penelitian yang dilakukan (Dewi dkk, 2015), (Nurlaela dkk, 2018), (Kurniawan dan Sutarmin, 2016) menyimpukan variabel Debt To Equity Ratio berpengaruh negatif terhadap ROA. Sedangkan menurut (Mahardika dan Marbun, 2016), (Rahmawati, 2009), (Ulzanah \& Murtaqi, 2015) menyimpulkan Debt To Equity Ratio berpengaruh terhadap ROA. Perusahaan yang memiliki Debt To Equity Ratio tinggi dianggap besar risiko yang diperolehnya karena hutang digunakan lebih besar dari ekuitas, sehingga memperoleh tingkat bunga yang begitu besar namun dapat menurunkan laba.

Penelitian yang dilakukan (Nurlaela dkk, 2016), (Dewi dkk, 2015), (Putra, 2017) menyimpulkan variabel Current ratio tidak berpengaruh terhadap ROA, sedangkan penelitian (Mahardika dan Marbun, 2016), (Rahmawati, 2009), (Kurniawan dan Sutarmin, 2016), (Ulzanah \& Murtaqi, 2015) menunjukkan bahwa variabel Current ratio memiliki pengaruh positif terhadap Profitabilitas. Current ratio yaitu rasio yang digunakan untuk mengukur kemampuan perusahaan dalam memenuhi kewajiban jangka pendeknya. Apabila tingkat likuiditas baik, perusahaan akan efektif dalam memperoleh laba serta investor lebih percaya untuk berinvestasi pada perusahaan.

Perkembangan dunia bisnis dapat di lihat dari indeks perdagangan saham. Perkembangan paling menonjol dari 5 negara yaitu London sebesar 6952,86 hal tersebut masih sangat jauh bagi 
IHSG dapat menunjukkan perkembangan indeks paling rendah senilai 6006,2. Perkembangan indeks harga saham gabungan di indonesia pada periode 2014, 5226,95 yang selanjutnya 4593,01 pada tahun 2015, 5296,71 pada tahun 2016, 6355, 65 pada tahun 2017, 6006,20 pada tahun 2018 dan hingga saat ini BEI mencatat perkembangan indeks harga saham gabungan pada industri barang konsumsi sebesar 19,94\% dari rata-rata perdagangan saham yang berjumlah 12,314,29 juta. Perkembangan indeks saham indonesia dengan negara lain dapat di gambarkan sebagai berikut :

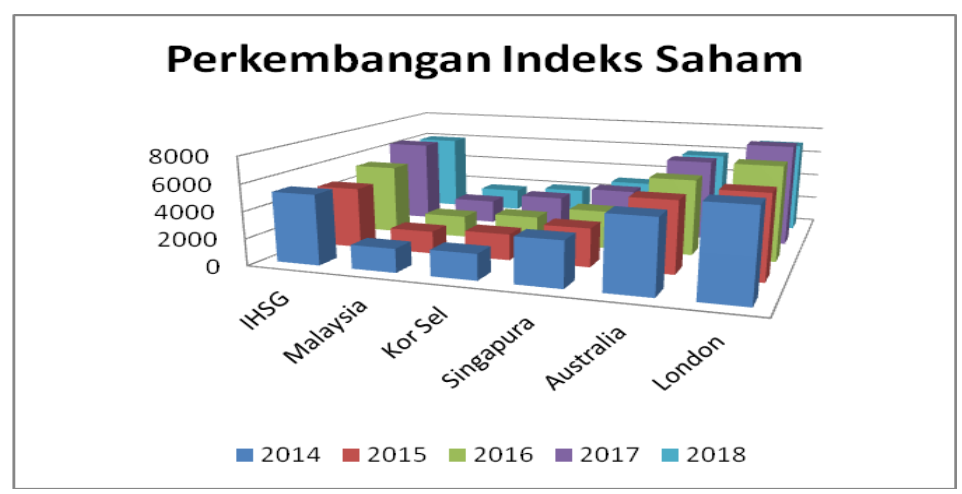

Sumber: Otoritas Jasa Keuangan 2018

\section{TINJAUAN PUSTAKA} Profitabilitas (ROA)

Profitabilitas (ROA) berpengaruh pada modal struktur, karena perusahaan akan lebih suka menggunakan pendanaan dari sumber internal, keuntungan yang diperoleh oleh perusahaan akan menggunakan hutang yang relatif kecil karena tingkat pengembalian yang tinggi memungkinkan perusahaan untuk membiayai sebagian besar pendanaannya dengan internal dana (Nurlaela dkk, 2018).

\section{Earning Per Share (EPS)}

Earning Per Share (EPS) merupakan perbandingan antara laba bersih dengan jumlah saham beredar. Earning Per Share (EPS) yang semakin tinggi maka akan menguntungkan pemegang saham karena semakin besar laba yang diberikan, sehingga akan meningkatnya harga saham (Ferawati, 2017).

\section{Debt To Equity Ratio (DER)}

Debt To Equity Ratio (DER) digunakan dalam operasi perusahaan semakin kecil, sehingga risiko ditanggung oleh investor juga akan semakin kecil dan akan mampu menaikkan harga dari stok. koefisien rasio hutang terhadap ekuitas Debt To Equity Ratio (DER) positif, ini menunjukkan kapan masing-masing peningkatan rasio hutang terhadap ekuitas satu persen (1\%), dengan asumsi variabel lain tetap, itu akan diikuti oleh pertumbuhan laba (Nurlaela dkk, 2018). 


\section{Current Ratio (CR)}

Current Ratio (CR) bertujuan untuk mengukur kemampuan suatu perusahaan dalam memenuhi kewajiban jangka pendeknya. Apabila tingkat likuiditas baik, perusahaan akan lebih efektif dalam menghasilkan laba (Esthirahayu dkk, 2014).

\section{Kerangka Konseptual}

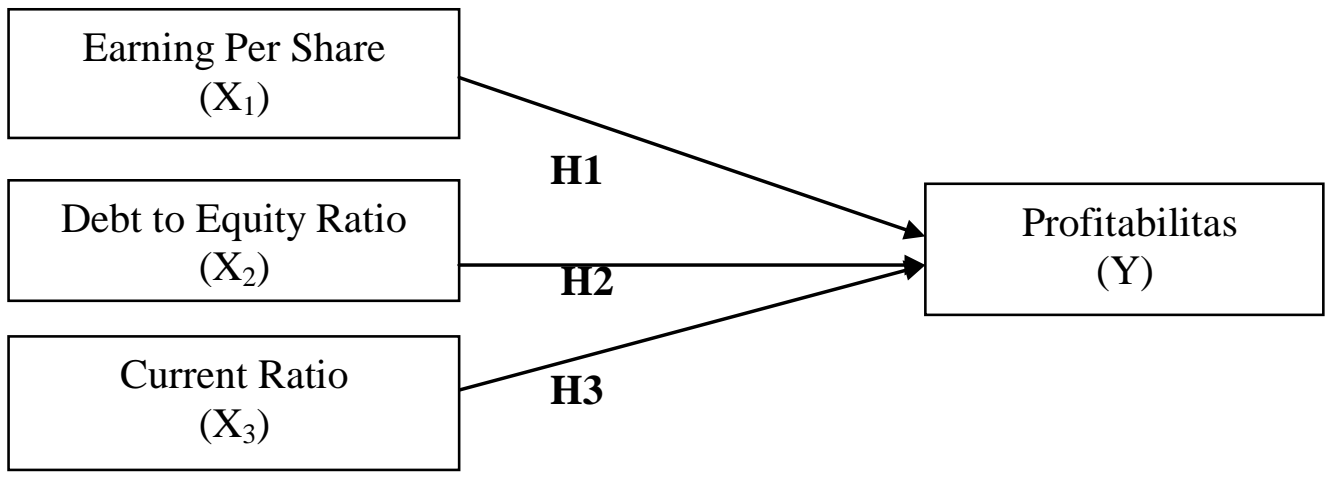

Keterangan :

$$
\begin{aligned}
& \mathrm{Y}=\text { Profitabilitas }(\mathrm{ROA}) \\
& \mathrm{X}_{1}=\text { Earning Per Share }(\mathrm{EPS}) \\
& \mathrm{X}_{2}=\text { Debt To Equity Ratio }(\mathrm{DER}) \\
& \mathrm{X}_{3}=\text { Current Ratio }(\mathrm{CR})
\end{aligned}
$$

\section{Hipotesis}

1) Pengaruh Earning Per Share (EPS) terhadap Profitabilitas (ROA)

Perusahaan dengan EPS (Earning Per Share) lebih tinggi akan menguntungkan perusahaan dengan menghasilkan laba tinggi. Keuntungan yang lebih tinggi akan meningkatkan pembilang untuk ROA, yang merupakan keuntungan. Meningkatnya angka dalam pembilang dapat menghasilkan rasio ROA yang lebih tinggi. Hasil ini didukung oleh (Diaz dkk, 2014) dan (Pramesthy, 2013) yang menyatakan bahwa Earning Per Share (EPS) tidak berpengaruh terhadap Profitabilitas (ROA).

\section{2) H1 = Earning Per Share tidak berpengaruh terhadap Profitabilitas}

Pengaruh Debt to Equity Ratio (DER) terhadap Profitabilitas (ROA) 
Nita Wedyaningsih, dkk/Edunomika Vol. 03, No. 01 (Februari 2019)

3) Perusahaan dengan DER (Debt To Equity Ratio) yang lebih tinggi dianggap lebih berisiko karena utang digunakan lebih dari ekuitas, itu akan menghasilkan tingkat bunga yang lebih tinggi yang akan menurunkan laba. Keuntungan yang lebih rendah akan menghasilkan nilai ROA yang lebih rendah. jadi, peningkatan nilai DER akan mengakibatkan penurunan nilai ROA. Hasil ini didukung oleh (Fitri Linda Rahmawati, 2009) temuan sebelumnya bahwa DER memiliki pengaruh negatif terhadap ROA. Penelitian yang dilakukan (Mahardika dan Marbun, 2016), (Rahmawati, 2009), (Ulzanah dan Murtaqi, 2015) menunjukkan bahwa Debt To Equity Ratio (DER) berpengaruh terhadap Profitabilitas (ROA). Sedangkan menurut (Dwi dkk, 2015), (Kurniawan dan Sutarmin , 2016) menunjukkan bahwa Debt To Equity Ratio (DER) tidak memiliki pengaruh terhadap ROA.

\section{H2 = Debt To Equity Ratio berpengaruh negatif terhadap Profitabilitas}

4) Pengaruh Current Ratio (CR) terhadap Profitabilitas (ROA)

a. Hubungan negatif terjadi karena perusahaan dengan rasio lancar yang lebih tinggi berarti perusahaan memiliki nilai aset lancar yang lebih tinggi karena dana tersebut lebih dialokasikan dalam aset lancar. Dana yang disediakan untuk memenuhi likuiditas perusahaan. Aktiva lancar yang lebih tinggi akan meningkatkan jumlah total aset dan itu akan menurunkan nilai laba atas aset karena pembilang untuk ROA adalah total aset. Hasil ini didukung oleh (Ulzanah dan Murtaqi, 2015) menunjukkan bahwa Current Ratio (CR) berpengaruh positif terhadap Profitabilitas (ROA).

\section{H3 = Current Ratio berpengaruh positif terhadap Profitabilitas}

\section{METODE PENELITIAN}

Sumber data yang digunakan dalam penelitian ini adalah data sekunder dari BEI. Populasi dalam penelitian ini adalah perusahaan sub-sektor barang konsumsi yang terdaftar di Bursa Efek Indonesia (BEI) tahun 2013-2017 dengan jumlah 49 perusahaan. Teknik pengambilan sampel yang digunakan yaitu metode purposive sampling didasarkan untuk memperoleh sampel yang mampu mewakili populasi, adapun telah diperoleh 55 sampel penelitian. Penelitian ini menggunakan metode analisis regresi linier berganda. 


\section{HASIL DAN PEMBAHASAN}

\section{1) Analisis Statistik Diskriptif}

Statistik deskriptif adalah statistik yang berfungsi untuk mendiskripsikan atau memberi gambaran terhadap obyek yang diteliti melalui sampel atau populasi sebagaimana adanya tanpa melakukan analisis dan membuat kesimpulan yang berlaku untuk umum (Sugiyono, 2012).

Tabel 1 Hasil Analisis Statistik Deskriptif

\begin{tabular}{lccccc}
\hline Variabel & $\mathrm{N}$ & Mean & Std. Deviation & Minimum & Maximum \\
\hline EPS & 55 & 167.3127 & 569.52541 & 0.38 & 4224.45 \\
DER & 55 & 0.8658 & 0.47179 & 0.23 & 1.95 \\
CR & 55 & 204.0196 & 104.35143 & 49.19 & 518.13 \\
ROA & 55 & 6.9502 & 3.88196 & 0.65 & 16.74 \\
\hline
\end{tabular}

Sumber: Output SPSS, 2018

Berdasarkan hasil analisis statistik deskriptif banyaknya data $(\mathrm{N})$ adalah 55 . Variabel Earning Per Share memiliki nilai mean 167.3127 dengan Std. Deviation 569.52541 nilai minimum 0.38 dan nilai maximum 4224.45. Variabel Debt To Equity Ratio memiliki nilai mean 0.8658 dengan Std. Deviation 0.47179 nilai minimum 0.23 dan nilai maximum 1.95. Variabel Current Ratio memiliki nilai mean 204.0196 dengan Std. Deviation 104.35143 nilai minimum 49.19 dan nilai maximum 518.13. Variabel Independen Return On Assets memiliki nilai mean 6.9502 dengan Std. Deviation 3.88196 nilai minimum 0.65 dan nilai maximum 16.74.

\section{2) Uji Asumsi Klasik}

\section{a. Hasil Uji Normalitas}

Uji normalitas bertujuan untuk menguji apakah dalam model regresi, variabel pengganggu atau residual memiliki distribusi normal. Pengujian dengan menggunakan uji statistik non-parametrik klomogorov-smirnov (K-S).

Tabel 2 Hasil Uji Normalitas Data

\begin{tabular}{lccc}
\hline Variabel & Kolmogorov-Smirnov & Sig. & Keterangan \\
\hline Unstandardized & 0.793 & 0.555 & Normal \\
Residual & & & \\
\hline Sumber : Output SPSS, 2018 & &
\end{tabular}

Berdasarkan hasil uji normalitas perhitungan Uji Kolmogorov-Smirnov dapat diketahui bahwa sig. sebesar $0.555>\alpha(0,05)$, sehingga data dalam penelitian ini berdistribusi normal. 
b. Hasil Uji Multikolinearitas

Uji multikolinearitas bertujuan untuk menguji apakah model regresi di temukan adanya korelasi antara variabel bebas (independen).

Tabel 3 Hasil Uji Multikolinieritas

\begin{tabular}{lccl}
\hline Variabel & Tolerance & VIF & Ketrangan \\
\hline EPS & 0.994 & 1.006 & Tidak Terjadi Multikolinieritas \\
DER & 0.783 & 1.277 & Tidak Terjadi Multikolinieritas \\
CR & 0.783 & 1.277 & Tidak Terjadi Multikolinieritas \\
\hline
\end{tabular}

Sumber : Output SPSS, 2018

Berdasaran hasil Uji Multikolinearitas diketahui bahwa nilai tolerance variabel Earning Per Share (EPS) sebesar 0.994 dan nilai VIF 1.006. Debt To Equity Ratio (DER) nilai tolerance sebesar 0.783 dan nilai VIF 1.277. Current Ratio (CR) nilai tolerance sebesar 0.783 dan nilai VIF 1.277. Dapat disimpulkan bahwa untuk semua variabel $<10$ dan nilai tolerance untuk semua variabel $>0.1$, sehingga tidak terjadi multikolinieritas.

c. Hasil Uji Autokorelasi

Uji Autokorelasi bertujuan untuk mengetahui apakah terdapat hubungan atau korelasi diantara rangkaian variabel yang diobservasi berdasarkan urutan waktu (times series) atau urutan ruang (cross section). Cara yang dilakukan untuk mengetahui ada atau tidaknya autokorelasi adalah dengan melakukan uji Durbin-Watson.

Tabel 4 Hasil Uji Autokorelasi

\begin{tabular}{ll}
\hline Durbin - Watson & Keterangan \\
\hline 1.856 & Tidak terjadi autokorelasi \\
\hline
\end{tabular}

Sumber : Output SPSS, 2018

Berdasarkan uji autokorelasi diperoleh nilai DW 1.856, dibandingkan dengan tabel $5 \%$ jumlah N 55 dan variabel independen 3, maka DU $=1.6815$. Nilai DW 1.859 lebih besar dari batas atas (DU) yakni 1.6815 dan kurang dari 4-dU, sehingga dapat disimpulkan bahwa tidak terjadi autokorelasi.

d. Hasil Uji Heteroskedastisitas

Uji heteroskedastisitas bertujuan menguji apakah dalam model regresi terjadi ketidaksamaan variance dari residual satu pengamatan ke pengamatan yang lain. Jika variance dari residual tetap maka disebut homokedastisitas dan jika berbeda maka disebut heteroskedastisitas. 
Tabel 5 Hasil Uji Heteroskedastisitas

\begin{tabular}{lclr}
\hline Variabel & Sig. & Keterangan & \\
\hline EPS & 0.424 & $\begin{array}{l}\text { Tidak } \\
\text { heteroskedastisitas }\end{array}$ & terjadi \\
DER & 0.656 & $\begin{array}{l}\text { Tidak } \\
\text { heteroskedastisitas }\end{array}$ & terjadi \\
CR & 0.493 & $\begin{array}{l}\text { Tidak } \\
\text { heteroskedastisitas }\end{array}$ & terjadi \\
& & &
\end{tabular}

Sumber : Output SPSS, 2018

Berdasarkan hasil Uji Heteroskedastisitas disimpulkan bahwa nilai sig. untuk seluruh variabel $>\alpha=0.05$. Hal ini mengindikasikan bahwa model regresi tidak terjadi heteroskedastisitas.

\section{3) Uji Hipotesis}

a. Analisis Regresi Linier Berganda

Analisis ini digunakan untuk mengetahui hubungan antara variabel independen dengan variabel dependen apakah masing-masing variabel independen berpengaruh dan untuk memprediksi variabel independen apakah mengalami kenaikan atau penurunan. Pada penelitian ini digunakan analisis regresi berganda dengan persamaan penelitian sebagai berikut :

$$
\mathrm{Y}=\mathrm{a}+\beta_{1} \mathrm{X}_{1}+\beta_{2} \mathrm{X}_{2}+\beta_{3} \mathrm{X}_{3}+\mathrm{e}
$$

Keterangan :

$\mathrm{Y}=$ Profitabilitas $(\mathrm{ROA})$

$\beta=$ Koefisien Regresi

$\mathrm{a}=$ Nilai Konstanta

$\mathrm{X}_{1}=$ Earning Per Share (EPS)

$\mathrm{X}_{2}=$ Debt To Equity Ratio (DER)

$\mathrm{X}_{3}=$ Current Ratio $(\mathrm{CR})$

$\mathrm{e}=$ Standart Error

Tabel 6 Hasil Analisis Regresi Linier Berganda

\begin{tabular}{cccccc}
\hline Variabel & $\mathrm{B}$ & $\mathrm{t}_{\text {hitung }}$ & $\mathrm{t}_{\text {tabel }}$ & Sig. & Keterangan \\
\hline (Constant) & 6.737 & 3.737 & & 0.000 & \\
EPS & 0.000 & 0.286 & 2.007 & 0.776 & Tidak Ada Pengaruh \\
DER & -2.315 & -2.040 & 2.007 & 0.047 & Ada Pengaruh \\
CR & 0.011 & 2.081 & 2.007 & 0.043 & Ada Pengaruh \\
\hline
\end{tabular}

Sumber : Output SPSS, 2018 
b. Uji Kelayakan Model (Uji F)

Uji Kelayakan Model pada dasarnya menunjukkan apakah permodelan yang dibangun memenuhi kriteria fit atau tidak, semua variabel bebas yang dimaksudkan dalam model mempunyai pengaruh terhadap variabel dependen. Pengujian dilakukan dengan menggunakan nilai signifikansi level 0,05 $(\mathrm{a}=5 \%)$ dan $\mathrm{df}=\mathrm{k} / \mathrm{n}-\mathrm{k}-1$.

Tabel 7 Hasil Uji Kelayakan Model (Uji F)

\begin{tabular}{lcccc}
\hline & $\mathrm{F}_{\text {hitung }}$ & $\mathrm{F}_{\text {tabel }}$ & Sig. & Keterangan \\
\hline $\begin{array}{l}\text { Regression } \\
\text { Residual }\end{array}$ & 5.378 & 2.79 & 0.003 & Ada Pengaruh \\
\hline
\end{tabular}

Sumber : Output SPSS, 2018

Berdasarkan hasil Uji Kelayakan Model (F) bahwa nilai F sebesar 5.378 dengan nilai signifikansi $0.003<0.05$, sehingga dapat disimpulkan bahwa variabel Earning Per Share, Debt To Equity Ratio dan Current Ratio mempunyai pengaruh terhadap Profitabilitas.

c. Uji Hipotesis (Uji t) Tabel 8 Hasil Uji Hipotesis (Uji t)

\begin{tabular}{cccccc}
\hline $\begin{array}{c}\text { Variabe } \\
1\end{array}$ & $\mathrm{t}_{\text {hitung }}$ & $\mathrm{t}_{\text {tabel }}$ & Sig. & $\alpha(\mathrm{sig})$. & Keterangan \\
\hline EPS & 0.286 & 2.007 & 0.776 & 0.05 & $\begin{array}{c}\text { Tidak ada } \\
\text { Pengaruh }\end{array}$ \\
DER & -2.040 & 2.007 & 0.047 & 0.05 & $\begin{array}{l}\text { Ada Pengaruh } \\
\text { CR }\end{array}$ \\
\hline
\end{tabular}

Sumber : Output SPSS, 2018

Berdasarkan uji hipotesis (t) Earning Per Share bahwa $t_{\text {hitung }}$ sebesar 0.286 dengan nilai Sig. $0.776<0.05$ sehingga dapat disimpulkan bahwa Earning Per Share tidak berpengaruh terhadap Profitabilitas. Debt To Equity Ratio bahwa hitung sebesar -2.040 dengan nilai Sig. $0.047>0.05$, sehingga dapat disimpulkan bahwa Debt To Equity Ratio mempunyai pengaruh negatif terhadap Profitabilitas. Current Ratio bahwa thitung sebesar 2.081 dengan nilai Sig. sebesar $0.043<0.05$, sehingga dapat disimpulkan bahwa Current Ratio mempunyai pengaruh positif terhadap Profitabilitas.

d. Analisis Koefisien Determinasi $\left(\mathrm{R}^{2}\right)$

Koefisien determinasi $\left(\mathrm{R}^{2}\right)$ pada dasarnya mengukur seberapa jauh kemampuan model dalam menerangkan variabel dependen. Nilai $\mathrm{R}^{2}$ yang kecil berarti kemampuan variabel independen dalam menjelaskan variabel dependen terbatas. 


\begin{tabular}{|c|c|c|c|c|}
\hline \multirow[b]{3}{*}{$\mathrm{R}$} & \multicolumn{4}{|c|}{ Tabel 9 Hasil Uji Koefisiensi Determinasi $\left(\mathrm{R}^{2}\right)$} \\
\hline & & Adjusted & & Keterangan \\
\hline & R Square & R2 Square & Sisanya & \\
\hline & & & & Variasi variabel independen \\
\hline $.490^{\mathrm{a}}$ & .240 & .196 & .760 & $\begin{array}{c}\text { berpengaruh sebesar } \\
0.240 \mathrm{atau} 24.0 \%\end{array}$ \\
\hline
\end{tabular}

Sumber: Output SPSS, 2018

Berdasarkan hasil Uji Koefisiensi Determinasi $\left(\mathrm{R}^{2}\right)$ nilai Adjusted $\mathrm{R}^{2}$ sebesar 0.240 yang berarti bahwa varibel Earning Per Share, Debt To Equity Ratio dan Current Ratio mempunyai pengaruh sebesar $24.0 \%$ terhadap Profitabilitas dan $76.0 \%$ dipengaruhi oleh variabel lainnya.

\section{KESIMPULAN}

Tujuan dari penelitian ini adalah untuk menguji dan menganalisis pengaruh Earning Per Share, Debt To Equity Ratio dan Current Ratio terhadap Profitabilitas pada perusahaan Sub-Sektor Barang Konsumsi yang terdaftar di Bursa Efek Indonesia periode 2013-2017. Dengan sampel data 55 melalui uji analisis regresi linier berganda.

Hasil pengujian secara serempak (Uji F) menunjukkan bahwa Earning Per Share, Debt To Equity Ratio dan Current Ratio berpengaruh terhadap Profitabilitas. Penelitian yang dilakukan oleh (Maqsood, Anwar, Raza, Ijaz \& Shouqat, 2016), (Ulzanah dan Murtaqi, 2015) menunjukkan bahwa Earning Per Share berpengaruh terhadap profitabilitas. Penelitian yang dilakukan (Dewi dkk, 2015), (Kurniawan dan Sutarmin, 2016) menunjukkan bahwa Debt To Equity Ratio tidak memiliki pengaruh terhadap ROA. Sedangkan menurut (Mahardika dan Marbun, 2016), (Rahmawati, 2009), (Ulzanah dan Murtaqi, 2015) menunjukkan bahwa Debt To Equity Ratio berpengaruh negatif terhadap ROA.

Hasil pengujian secara parsial (Uji t) menunjukkan Earning Per Share tidak memiliki pengaruh terhadap Profitabilitas perusahaan, sedangkan Debt To Equity Ratio berpengaruh negatif terhadap profitabilitas dan Current Ratio berpengaruh positif terhadap Profitabilitas. Penelitian yang dilakukan (Dewi dkk, 2015), (Putra, 2017) menunjukkan bahwa Current Ratio tidak berpengaruh terhadap ROA, sedangkan penelitian (Mahardika dan Marbun, 2016), (Rahmawati, 2009), (Kurniawan dan Sutarmin, 2016), (Ulzanah dan Murtaqi, 2015) menunjukkan bahwa Current Ratio berpengaruh terhadap Profitabilitas.

\section{DAFTAR PUSTAKA}

Dewi dkk. (2015). Pengaruh LDR, LAR, DER dan CR Terhadap ROA. e-Journal Bisma Pendidikan Ganesha Jurusan Manajemen , 03. 
Nita Wedyaningsih, dkk/Edunomika Vol. 03, No. 01 (Februari 2019)

Esthirahayu dkk. (2014). Pengaruh Rasio Likuiditas, Rasio Leverage dan Rasio Aktivitas Terhadap Kinerja Keuangan Perusahaan. Jurnal Administrasi Bisnis (JAB) , 08, Nomor 01., 1-9.

Ferawati. (2017). Analisis Pengaruh Rasio Lancar, Laba Bersih Margin, Earning Per Share dan Return On Equity Terhadap Harga Saham Perusahaan Manufaktur Sub-Sektor Makanan dan Minuman Yang Terdaftar Di Bursa Efek Indonesia Periode 2012-2016. Jurnal Universitas Nusantara PGRI.

Joana dan Pitaloka. (2017). Pengaruh Earning Per Share Terhadap Return On Assets Serta Dampaknya Terhadap Harga Saham. Jurnal Bisnis dan Manajemen , 04, Nomor 02., 80-85.

Kurniawan dan Sutarmin. (2016). Pergaruh Rasio Likuiditas dan Rasio Solvabilitas Terhadap Profitabilitas dengan Penggunaan Teknologi Informasi Sebagai Variabel Moderasi. Jurnal Bisnis dan Manajemen .

Mahardika dan Marbun. (2016). Pengaruh Current Ratio dan Debt To Equity Ratio Terhadap Return On Assets. Jurnal Bisnis dan Manajemen , 03, 23-28.

Nurlaela dkk. (2018). Faktor-faktor Yang Mempengaruhi Kinerja Keuangan Perusahaan Manufaktur Yang Terdaftar Di Bursa Efek Indonesia. . Konferensi Internasional Tentang Teknologi, Pendidikan dan Ilmu Sosial. , 65-72.

Nurlaela dkk. (2018). Pengaruh Rasio Keuangan Terhadap Pertumbuhan Laba Pada Perusahaan Manufaktur Yang Terdaftar Di Bursa Efek Indonesia. Konferensi Internasional Tentang Teknologi, Pendidikan dan Ilmu Sosial. , 517-524.

Nurlaela dkk. (2016). Pengaruh Rasio Likuiditas, Rasio Leverage, Rasio Aktivitas dan Firm Size Terhadap Profitabilitas Perusahaan Sub-Sektor Otomotif dan Komponen Di Bursa Efek Indonesia. Seminar Nasional IENACO , 810-817.

Nurlaela dkk. (2018). Pengaruh Struktur Aset, Likuiditas, Ukuran Perusahaan dan Profitabilitas Struktur Modal. (Studi Empiris Pada Perusahaan Manufaktur Yang Terdaftar Di Bursa Efek Indonesia). Konferensi Internasional Tentang Teknologi, Pendidikan dan Ilmu Sosial. , 107117.

Putra. (2017). Pengaruh Likuiditas dan Solvabilitas Terhadap Profitabilitas Pada Perusahaan Yang Terdaftar Di Bursa Efek Indonesia (BEI) Periode 2011-2015. Jurnal Online Mahasiswa (JOM) Bidang Akuntansi , 02, Nomor 02.

Rahmawati. (2009). Pengaruh Current Ratio dan Debt To Equity Ratio Terhadap Return On Assets (Study Pada Perusahaan Food and Beverage Yang Listing Di Bursa Efek Indonesia Tahun 2017-2019). Jurnal Ilmiah Manajemen Universitas Negeri Malang , 02, Nomor 02. 
Nita Wedyaningsih, dkk / Edunomika Vol. 03, No. 01 (Februari 2019)

Ulzanah dan Murtaqi. (2015). The Impact Of Earning Per Share, Debt To Equity Ratio And Current Ratio Towards The Profitability Companies Listed In LQ45 From 2009 To 2013. Journal Business And Management , 04, Nomor 01., 18-27. 